\title{
ENERGY EFFICIENCY AND ECONOMETRIC ANALYSIS OF ORGANIC KIWIFRUIT (ACTINIDIA DELICIOSA A. CHEV.) PRODUCTION
}

\author{
SunNy Sharma ${ }^{1}$ and Vishal Singh Rana* \\ Department of Fruit Science, College of Horticulture, Dr. Yashwant Singh Parmar University of \\ Horticulture and Forestry, Nauni, Himachal Pradesh 173230, India
}

Keywords: Actinidia deliciosa, Benefit-cost ratio, Econometric analysis, Energy output-input, Organic production

\begin{abstract}
The energy exchange ratio of cultivation and different parameter values of input affecting the organic production of kiwifruit in the mid-hill Himalayan region of India during 2017 and 2018 was determined. The experimental trial was divided into 7 organic treatment i.e. $\mathrm{T}_{1}$ to $\mathrm{T}_{3}$ was sole application on equivalence 100 per cent Dairy manure (DM), Vermicompost (VC) and Poultry manure, $\mathrm{T}_{4}$ to $\mathrm{T}_{7}$ was a compound application of 50: 50 DM: PM, DM: VC and VC: $\mathrm{PM}$ and $\mathrm{T}_{7}$ in which $\mathrm{DM}=\mathrm{PM}=\mathrm{VC}$ applied on $\mathrm{N}$ equivalence. Five foliar sprays of organic formulation were applied in each of the treatment. The Energy efficiency and econometric analysis of organic kiwifruit production were examined. The highest energy inputs unit per hectare was utilized by $\mathrm{T}_{1}$ out of which over 86 per cent were from organic manure inputs and provided 26401.02 MJ/ha. The highest yield per hectare, as well as the output energy were observed in the treatment $\mathrm{T}_{5}$. Whereas the highest energy ratio, energy productivity, and specific energy were recorded under $T_{2}$. Likewise, the highest productivity ratio and benefit-cost ratio were recorded under $\mathrm{T}_{7}$ which was followed by $\mathrm{T}_{2}$. From a farming point of view, the $\mathrm{T}_{2}$ gave the superior result because it has provided optimum amount output along with maximum returns.
\end{abstract}

\section{Introduction}

The agricultural concept of $21^{\text {st }}$ century relies on low cost crop production, increased nutrient use efficiency, and improving the environmental quality. The cultivation of kiwifruit under inorganic fertigation leads to increased cost of production, soil degradation, leaching of nutrients, and conversion of soil nutrients into non available form. However, kiwifruit has high nutritive value being a rich source of vitamin C. It has gained popularity due to potential health benefits, like a source of antioxidants, lowering of blood lipids and improvement of gastrointestinal laxation (Singletary 2012). The kiwifruit production strategy in mid hills of Himalayan region for future should be based on the high production with less use of input which will lead to increase farmer income and improve the soil quality. The main emphasis should be given on the conservation of natural resources like soil, water from the overuse of agrochemicals (Ayala and Rao 2002). It was estimated that 30 per cent of organic product of the world is present in India with cultivating 1.78 million hectares out of 69.8 million hectares of the total cultivated area (Willer et al. 2018). At the same time, maximum numbers of the farmers are struggling because of the poor policies of their government regarding organic products and low market demand. Organic farming maintains ecosystem service, therefore it is more sustainable than modern agriculture, which degrades some ecosystem services (Sandhu et al. 2008). Organic fruit production has gained momentum in recent years by consumer demand as well as higher price which have prompted producers to grow fruit crops organically. Organic kiwifruit farming is of paramount importance as there is less biotic and abiotic stress under mid hill condition. The

*Author for correspondence: <vishalranafrs@yspuniversity.ac.in>. ${ }^{1}$ Department of Fruit Science, College of Horticulture, Dr. Yashwant Singh Parmar University of Horticulture and Forestry, Nauni, Himachal Pradesh 173230, India. 
kiwifruit orchardists are mainly dependent on different energy resources such as electricity, fuels, agrochemicals, etc. The use of energies in efficient way would lead to optimum quality fruit production and also contributes to the national economy and increase farmers profitability. The resulted outcome from plant (fruit and by products) is known as output energy. The development of input of system of energy compared to the output of products should therefore help to reduce the emissions of greenhouse gases (GHG's) in agricultural production (Kızlaslan 2009).

Energy efficiency contributes to the economy in the rural area with the competitiveness of sustainable agriculture, increased profitability, and productivity (Mohamaddi et al. 2010). In addition, the benefit-cost ratio, the use of direct and indirect energy, renewable and non-renewable energy were determined. Several researches have been performed on energy input- output analysis of agricultural products and the environmental impact of energy efficiency. For example, researches have been done on energy input-output analyses of organic fruit crops like citrus (Yilmaz and Aydin 2020), grape (Baran et al. 2017a), walnut (Baran et al. 2017b), mulberry (Gokdogan et al. 2017), lemon (Bilgili 2012), and cherry (Kizilaslan 2009). Although many experimental works have been done on energy input-output analysis in horticulture, there is no study on the energy input-output analysis of organic kiwifruit production. In the present study, the energy efficiency of kiwifruit production, net energy, energy productivity, and specific energy were assessed. Besides the energy input-output analysis of organic kiwifruit production was also evaluated. Since the information for kiwifruit cv. Allison is lacking, therefore, an effort was also made to compute data on energy use pattern, energy input, output ratio and economic analysis of kiwifruit production to help the growers.

\section{Material and Methods}

The experiment block was situated at an elevation of $1260 \mathrm{~m}$ above mean sea level with latitude of $30^{\circ} 50^{\prime}$ North and longitude of $77^{\circ} 11^{\prime} 30^{\prime \prime}$ East. The average annual rainfall of the area is about $100-130 \mathrm{~cm}$. A field experiment was laid out by using randomized block design with 3 replications for 9 years old vine of kiwifruit $\mathrm{cv}$, Allison at an experimental block of the Department of Fruit Science, Dr YS Parmar UHF, Nauni, Solan, HP, India. Data were recorded from seven different treatment combinations comprising $200 \mathrm{~kg}$ Dairy Manure (100\% DM- $\mathrm{T}_{1}$ );

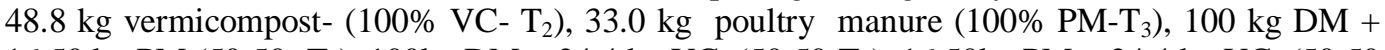
$16.50 \mathrm{~kg}$ PM (50:50- $\left.\mathrm{T}_{4}\right), 100 \mathrm{~kg} \mathrm{DM}+24.4 \mathrm{~kg} \mathrm{VC}\left(50: 50-\mathrm{T}_{5}\right), 16.50 \mathrm{~kg} \mathrm{PM}+24.4 \mathrm{~kg} \mathrm{VC}(50: 50$ $\mathrm{T}_{6}$ ), $\mathrm{DM} 66.50 \mathrm{~kg}+8.250 \mathrm{~kg} \mathrm{PM}+16.24 \mathrm{~kg} \mathrm{VC} \mathrm{t}$ (equal proportion- $\mathrm{T}_{7}$ ) on $\mathrm{N}$ equivalence were in use for estimation of energy. In addition to these treatments, 5 sprays of liquid organic formulation were applied. Kiwifruit vines of the variety 'Allison' were carefully chosen for the experiment and were planted in 2009, T-bar trained, with rows oriented north-south at a spacing of $4.0 \mathrm{~m} \times 6.0 \mathrm{~m}$ (416 vines/ha), the female: male ratio was 9:1 out which 376 were female.

The energy inputs were estimated based on the time required for each operation (schedule), a number of manpower, machinery and inputs used such as manures and liquid formulations (Tsatsarelis 1993). The energy equivalent of the inputs used in the production of the kiwifruit is presented in Table 1. The Energy used in cultural operations like tillage, irrigation, manures and foliar application, spraying, harvesting, transportation etc. in kiwifruit is also shown in Table 1. The human activity was calculated by this conversion factor i.e. one man-hour $=1.96 \mathrm{MJ} / \mathrm{ha}$ (Table 1). The energy effectiveness parameters were used to determine the relationship between energy consumption and total output and production per hectare. The Energy ratio, specific energy, energy productivity, energy intensiveness and net energy yield were measured as recommended by Mani et al. (2007). This ratio is generally higher in lower and higher energy input, which indicates the law of diminishing return. Gross profit, net return and benefit cost ratio 
was worked out keeping sale price of kiwifruit $1.34 \$ / \mathrm{kg}$. Energy efficiency is a useful tool to measure economic efficiency of crop production.

$$
\begin{array}{lll}
\text { Energy Ratio } & = & \text { energy output }(\mathrm{MJ} / \mathrm{ha}) / \text { energy input }(\mathrm{MJ} / \mathrm{ha}) \\
\text { Specific energy } & = & \text { energy input }(\mathrm{MJ} / \mathrm{ha}) / \text { output }(\mathrm{MJ} / \mathrm{ha}) \\
\text { Energy productivity } & = & \text { output }(\mathrm{kg} / \mathrm{ha}) / \mathrm{energy} \text { input }(\mathrm{MJ} / \mathrm{ha}) \\
\text { Net energy yield } & = & \text { energy output }(\mathrm{MJ} / \mathrm{ha})-\text { energy input }(\mathrm{MJ} / \mathrm{ha})
\end{array}
$$

Production value, gross profit, productivity, net return and benefit cost ratio was worked out as per following formula.

Total production value $=$ Kiwifruit yield $(\mathrm{kg} / \mathrm{ha}),{ }^{*}$ Kiwifruit price $(\$ / \mathrm{kg})$

Gross profit $\quad=$ Total production value $(\$ / \mathrm{ha})-$ Total production costs $(\$ / \mathrm{ha})$

Productivity $\quad=$ Kiwifruit yield $(\mathrm{kg} / \mathrm{ha}) /$ Total production costs $(\$ / \mathrm{ha})$

Net return $\quad=$ Total production value $(\$ / \mathrm{ha})-$ Total production cost $(\$ / \mathrm{ha})$

Benefit-cost ratio $\quad=$ Total production value $(\mathrm{kg} / \mathrm{ha}) /$ Total production cost $(\$ / \mathrm{ha})$

Net energy yield $\quad=$ energy output $(\mathrm{MJ} / \mathrm{ha})-$ energy input $(\mathrm{MJ} / \mathrm{ha})$

Table 1. Energy equivalents of inputs and output in organic kiwifruit production.

\begin{tabular}{lccl}
\hline Inputs & Unit & $\begin{array}{c}\text { Energy equivalent } \\
\left(\text { MJ unit }^{-1}\right)\end{array}$ & References \\
\hline Human labour & $\mathrm{H}$ & 1.96 & \\
Soil application & $\mathrm{H}$ & 1.96 & \\
Spraying & $\mathrm{H}$ & 1.96 & Mohamaddi et al. 2010 \\
Cultural practices & $\mathrm{H}$ & 1.96 & \\
Harvesting & $\mathrm{H}$ & 1.96 & \\
Transportation & $\mathrm{H}$ & 1.96 & \\
Machinery & $\mathrm{H}$ & 41.4 & \\
Farmyard manure & $\mathrm{Kg}$ & .30 & \\
Poultry manure & $\mathrm{Kg}$ & .50 & \\
Vermicompost $(\mathrm{kg})$ & $\mathrm{Kg}$ & .50 & \\
Panchgavya & $\mathrm{Kg}$ & 1.0 & \\
Jeevamrit & $\mathrm{L}$ & 1.0 & \\
Diesel-oil & $\mathrm{L}$ & 56.31 & \\
Electricity & $\mathrm{kWh}$ & 11.93 & Ozkan et al. 2004 \\
Irrigation water & $\mathrm{m}$ & .63 & \\
Output & & & \\
Kiwifruit & $\mathrm{Kg}$ & 1.90 & Mohamaddi et al. 2010 \\
\hline
\end{tabular}




\section{Results and Discussion}

The total energy consumed (Table 3 ) in terms of manpower, machinery and organic manures was 26401.02 with application of $100 \% \mathrm{DM} \mathrm{T}_{1}$ which was followed by the $\mathrm{T}_{5}>\mathrm{T}_{4}>\mathrm{T}_{7}>\mathrm{T}_{2}>\mathrm{T}_{6}$ $>\mathrm{T}_{3}$, recording 23267.26, 21493.94, 20194.75, 17539.54 and $15809.34 \mathrm{Mj}$ per hectare respectively. It is apparent from the data that energy consumption with $200 \mathrm{~kg} / \mathrm{vine}$ FYM was the highest (26401.02 MJ) (Table 2). The various input namely human labour consumed the highest energy after organic manures as compared to irrigation in all treatments of kiwifruit production, machinery consumed approx. same input energy in all the treatments, (Table 2). The percentage usage of unit energy per hectare followed the same trend as followed energy input provided. Organic manures were the highest energy-consuming input and varied from 12379.22 to 26401.02 $\mathrm{MJ} / \mathrm{ha}$ in all the treatments. This might be due to the high transportation cost of the bulky organic manures. Similar results were reported by many researchers in different crops, parallel result of energy use in machinery and higher energy use for organic manures in various fruits crop production (Pimental et al. 1983; Strapatsa et al. 2006). Lower energy in machinery and diesel were reported for moderate high yield plantation of apple orchards in the eastern US (Pimental et al. 1983) because organic manures reduce incidence weeding and hoeing ploughing and improve the water capacity of the soil.

Table 2. Amount of unit requirement and energy input along with per cent share of input energy.

\begin{tabular}{|c|c|c|c|c|c|c|c|}
\hline & \multicolumn{7}{|c|}{ Unit/ ha } \\
\hline & $\mathrm{T}_{1}$ & $\mathrm{~T}_{2}$ & $\mathrm{~T}_{3}$ & $\mathrm{~T}_{4}$ & $\mathrm{~T}_{5}$ & $\mathrm{~T}_{6}$ & $\overline{\mathrm{T}_{7}}$ \\
\hline Human labour & 1020 & 950 & 945 & 1002 & 1010 & 975 & 998 \\
\hline Machinery & 13.55 & 13.55 & 13.55 & 13.55 & 13.55 & 13.55 & 13.55 \\
\hline Organic manures & 75200 & 18348 & 12408 & 43804 & 46774.4 & 15378.4 & 35318.8 \\
\hline Diesel oil & 12 & 12 & 12 & 12 & 12 & 12 & 12 \\
\hline Irrigation & 600.13 & 600.13 & 600.13 & 600.13 & 600.13 & 600.13 & 600.13 \\
\hline \multirow[t]{3}{*}{ Spraying } & 5 & 5 & 5 & 5 & 5 & 5 & 5 \\
\hline & \multicolumn{7}{|c|}{ Energy input MJ/ha } \\
\hline & $\mathrm{T}_{1}$ & $\mathrm{~T}_{2}$ & $\mathrm{~T}_{3}$ & $\mathrm{~T}_{4}$ & $\mathrm{~T}_{5}$ & $\mathrm{~T}_{6}$ & $\mathrm{~T}_{7}$ \\
\hline Human labour & 1999.2 & 1862 & 1852.2 & 1963.92 & 1979.6 & 1911 & 1956.08 \\
\hline Machinery & 560.97 & 560.97 & 560.97 & 560.97 & 560.97 & 560.97 & 560.97 \\
\hline Organic manures & 22560 & 9174.4 & 8685.6 & 15622.8 & 15867 & 8929 & 13472.3 \\
\hline Diesel oil & 675.72 & 675.72 & 675.72 & 675.72 & 675.72 & 675.72 & 675.72 \\
\hline Irrigation & 600.13 & 600.13 & 600.13 & 600.13 & 600.13 & 600.13 & 600.13 \\
\hline \multirow[t]{4}{*}{ Spraying } & 5 & 5 & 5 & 5 & 5 & 5 & 5 \\
\hline & 26401.02 & 12878.22 & 12379.62 & 19428.54 & 19688.42 & 12681.82 & 17270.2 \\
\hline & \multicolumn{7}{|c|}{ Percentage of Energy Input used } \\
\hline & $\mathrm{T}_{1}$ & $\mathrm{~T}_{2}$ & $\mathrm{~T}_{3}$ & $\mathrm{~T}_{4}$ & $\mathrm{~T}_{5}$ & $\mathrm{~T}_{6}$ & $\mathrm{~T}_{7}$ \\
\hline Human labour & 7.57 & 14.45 & 14.96 & 10.10 & 10.05 & 15.06 & 11.32 \\
\hline Machinery & 2.12 & 4.35 & 4.53 & 2.88 & 2.84 & 4.42 & 3.24 \\
\hline Organic manures & 85.45 & 71.23 & 70.16 & 80.41 & 80.59 & 70.40 & 78.00 \\
\hline Diesel oil & 2.55 & 5.24 & 5.45 & 3.47 & 3.43 & 5.32 & 3.91 \\
\hline Irrigation & 2.27 & 4.66 & 4.84 & 3.08 & 3.04 & 4.73 & 3.47 \\
\hline Spraying & 0.01 & 0.03 & 0.04 & 0.02 & 0.02 & 0.03 & 0.02 \\
\hline Total $\%$ age & 100.00 & 100.00 & 100.00 & 100.00 & 100.00 & 100.00 & 100.00 \\
\hline
\end{tabular}




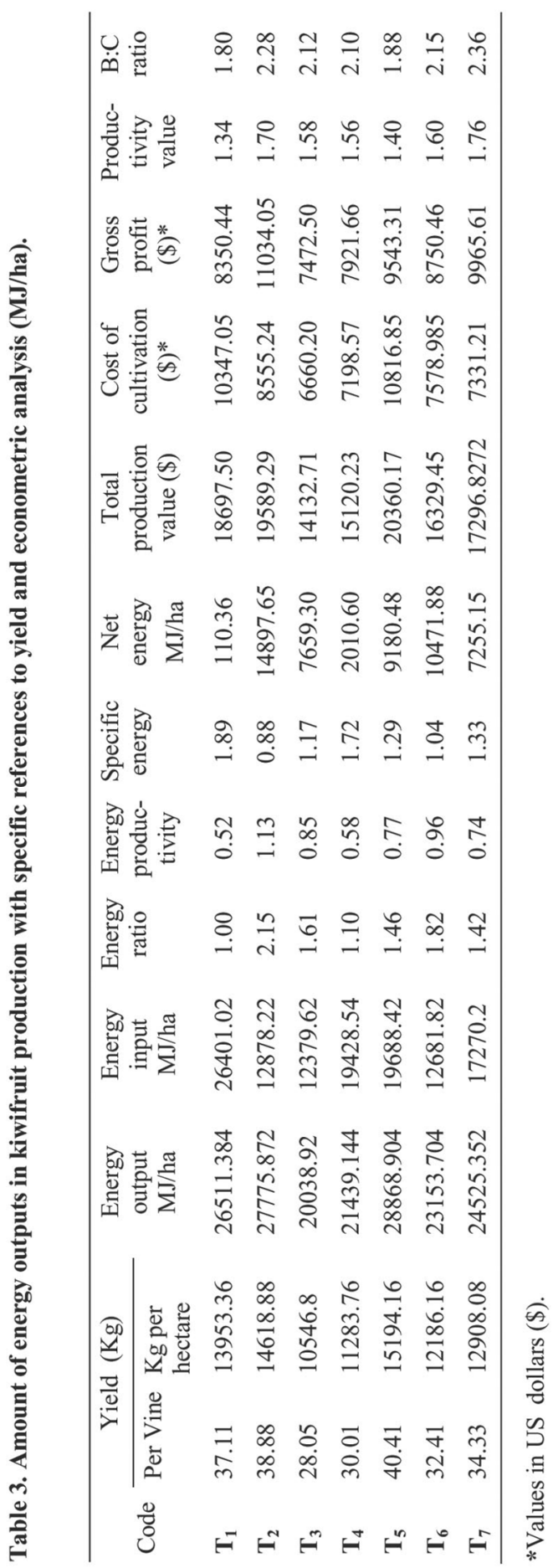


The new method of energy combines with usual concepts of economics to evaluate and optimize the design and performance of energy systems. Energy analysis and economical production system could be the more inclusive mode for the best management strategies. The highest crop yield and energy output (Table 3 ) was recorded with the $\mathrm{T}_{5}$ i.e. application DM along with vermicompost which was followed by $\mathrm{T}_{2}$. The highest energy ratio, energy productivity net energy and gross profit were recorded with the application of vermicompost (100\%) on $\mathrm{N}$ equivalence, recording 2.15, $1.1314897 .65 \mathrm{MJ} / \mathrm{ha}$ and 11034.05 \$, respectively. Whereas, the lowest value of specific energy was observed with $\mathrm{T}_{2}$.

The cost-economics analysis of kiwifruit production is presented in Table 3. The observation showed that the total production value $(20360.17$ \$/ha) was the highest with the application of 50 per cent $\mathrm{DM}$ and 50 per cent VC $\left(\mathrm{T}_{5}\right)$. The highest productivity value $(0.431)$ and benefit cost ratio (2.36) was found with the application of DM, VC and PM which was followed by $\mathrm{T}_{2}$. Similar studies were also conducted previously to determine energy usage efficiency in organic apricot, banana, apple production, and the energy usage efficiency value by Yilmaz and Aydin (2020). Organic kiwifruit production is a profitable production in terms of energy usage efficiency. Some of the benefits desired to be obtained through energy input/output analysis are summarized as: being able to evaluation whether energy has been used effectively or not. Once this is determined, then energy wastage will be avoided, as use of excessive energy will be avoided, which in turn, will lower the negative effects caused by environmental exposure of excessive energy, fuel, etc. in peach (Göktolga et al. 2006). Demircan et al. (2006) reported that proper tractor selection and management of machinery to decrease direct use of diesel fuel are needed to save non-renewable energy sources without impairing the yield or profitability of sweet cherry production. Similar results on the energy input-output analyses of organic fruit crops were also reported for several crops, like grape (Baran et al. 2017a), walnut (Baran et al. 2017b) mulberry (Gokdogan et al. 2017), lemon (Bilgili 2012), kiwifruit (Mohamadi et al. 2010) and cherry (Kizilaslan 2009).

In conclusion, various energy analyses based on input and output sources pattern were done in kiwifruit production system. Organic production system is an emerging system towards the approach of sustainable fruit product. The highest energy inputs units per hectare were utilized by $\mathrm{T}_{1}$ out of which over 86 per cent were from organic manure inputs. The highest yield per hectare, as well as the output energy, were observed in the treatment $T_{5}$ which was followed by $T_{2}$. Whereas, the highest energy ratio, energy productivity, and specific energy were recorded under $T_{2}$. Likewise, the highest productivity ratio and benefit-cost ratio recorded under $T_{7}$ was followed by $T_{2}$. Therefore, $T_{2}$ gave the superior result as because the treatment provided optimum amount of output along with maximum returns.

\section{Acknowledgements}

The authors gratefully acknowledge the Department of Fruit Science, Dr. YSP University of Horticulture \& Forestry, Nauni, Solan, Himachal Pradesh for providing the necessary facility.

\section{References}

Ayala S and Rao EP 2002. Perspectives of soil fertility management with a focus on fertilizer use for crop productivity. Curr. Sci. 82: 797-807.

Baran MF, Lule F and Gokdogan O 2017a. Energy input-output analysis of organic grape production: a case study from Adiyaman province. Erwerbs-Obstbau. 59: 275-279.

Baran MF, Oguz HI and Gokdogan O 2017b. Determination of energy input-output analysis in organic strawberry production. Fres. Environ. Bull. 26: 2076-2081 
Bilgili ME. 2012 Determination of energy using efficiency in lemon production, Adana. J Agric Mach Sci 8(2):199-203 (in Turkish) Bojaca CR, Schrevens E (2010) Energy assessment of peri-urban horticulture and its uncertainty: Case study for Bogota, Colombia. Ener. 35: 2109-2118

Demircan V, Ekinci K, Keener HM, Akbolat D and Ekinci C 2006. Energy and economic analysis of sweet cherry production in Turkey: A case study from Isparta province. Energy Convers. Manag. 47: 17611769

Gokdogan O, Oguz HI and Baran MF 2017. Energy input-output analysis in organic mulberry (Morus spp.) production in Turkey: a case study Adiyaman-Tut Region. Erwerbs-Obstbau. 59: 325-330.

Goktolga ZG, Gozener B and Karkacier O 2006. Energy use in peach production. Case of Tokat province. J. Agric. Fac. Gaziosmanpasa. Univ. 23: 39-44 .

Kizilaslan H 2009. Input-output energy analysis of cherries production in Tokat Province of Turkey. App. Energy. 86: 1354-8.

Mani I, Kumar P, Panwar JS, Kant K 2007. Variation in energy consumption in production of wheat-maize with varying altitudes in hilly regions of Himachal Pradesh, India. Energy. 32: 2336-2339.

Mohammadi A, Rafiee S, Mohtasebi SS and Rafiee H 2010. Energy inputs-yield relationship and cost analysis of kiwifruit production in Iran. Renew. Ener. 35: 1071-1075.

Ozkan B, Akcaoz H and Karadeniz F 2004. Energy requirement and economic analysis of citrus production in Turkey. Energy. Convers. Manag. 45: 1821-1830

Pimentel D, Berardi G and Fast S 1983. Energy efficiency of farming systems: organic and conventional agriculture. Agr. Ecosys. \& Environ. 9: 359-72.

Ram RA and Verma AK. 2017. Energy input, output and economic analysis in organic production of guava (Psidium guajava) cv. Allahabad Safeda. Ind. J. Agric. Sci. 87: 462-466.

Sandhu HS, Wratten SD, Cullen R and Case B 2008. The future of farming: the value of ecosystem services in conventional and organic arable land. An experimental approach. Ecolo. Econo. 64:835-848.

Singletary K 2012. Kiwifruit-overview of potential health benefits. Nutr . Food 47: 133-147.

Strapatsa AV, Nanos GD and Tsatsarelis CA. 2006. Energy flow for integrated apple production in Greece. Agr. Ecosys. \& environ. 116: 176-180.

Tsatsarelis CA 1993. Energy inputs and outputs for soft winter wheat production in Greece. Agr. Ecosys. \& Environ. 43: 109-118.

Willer H, Lernoud J, Kemper L 2018. The world of organic agriculture 2018: Summary. In The World of Organic Agriculture. Statistics and Emerging Trends 2018 (pp. 22-31). Research Institute of Organic Agriculture FiBL and IFOAM-Organics International.

Yilmaz H and Aydin B 2020. Comparative Input-Output Energy Analysis of Citrus Production in Turkey: Case of Adana Province. Erwerbs-Obstbau 62: 29-36. 